\title{
ENTREPRENEURSHIP IN THE DEVELOPMENT OF SYLVAN TOURISM
}

\author{
MIKOŁAJ JALINIK \\ Bialystok University of Technology, POLAND \\ e-mail: jalinik@op.pl
}

RECEIVED
ACCEPTED
JEL
CLASSIFICATION
KEYWORDS

ABSTRACT

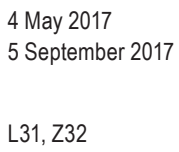

$\mathrm{L} 31, \mathrm{Z} 32$

entrepreneurship, sylvan tourism, tourist attractions, tourist values

Different forms of leisure activities are being developed in different areas in all regions in Poland. The choice of localities and specific places depends primarily on tourist values and attractions as well as the prices of services. Considering natural and landscape, as well as cultural values, on the other hand, this confirms the belief in the fantastic opportunity and possibilities of having a rest in such areas. Apart from tourist values and attractions, using the offer also depends on the anthropogenic values and attractions. In this case, entrepreneurship, which is the driving force behind the development of tourism and recreation, is very important. On the other hand, it brings a profit to the inhabitants of forest areas buffer zones. Entrepreneurship is where entrepreneurial people (creative, risky, resourceful) live and work. The more there are entrepreneurial people in each area, the more tourists are likely to visit this area, and at the same time their family budget is likely to improve.

\section{Introduction}

In business activity three concepts are usually used: enterprise, entrepreneur and entrepreneurship. The most important economic factor, however, is the entrepreneur (a human factor). The way the business operates depends on it - irrespective whether it is large, medium, small or micro-enterprise. The results of a given entity will also depend on the entrepreneur, that is whether he or she will be entrepreneurial, and to what extent it will find its 
fulfillment. In tourism, this is particularly important due to the seasonal character of functioning of most tourist facilities and the development of tourism.

Entrepreneurs should act in an entrepreneurial way, and entrepreneurship in common language is synonymous with such words as resourcefulness, activity and ingenuity. According to A. Gaweł the most common businessrelated key-words are the following: starting, setting up, creating a new company, innovations, new products, new markets, exploring opportunities, risk taking, profit seeking, new resource combinations, management, resource acquisition and value creation (Gaweł, 2007). The concept of entrepreneurship today should be understood in a bit broader way, as it should also be associated with such attributes and attitudes as creativity, dynamism, flexibility, the pursuit of growth and tendency to take risk. In Europe, the leading role of business entities as a driving force for economic growth and diversification has been recognized for a long time.

Entrepreneurial behavior depends on the individual characteristics of a person, his or her skills, and mainly the perception of in an objectively complex situation a chance that can bring certain benefits and it also depends on the existing motivation system.

The aim of the study is to present the importance of entrepreneurship in the broadly defined development of sylvan tourism. By observing and discussing with the owners of tourist facilities about the activities of their subjects, the author was convinced that everyone is an entrepreneur, but when it comes to specific achievements, then, in practice, entrepreneurship cannot be seen. The questions concerned mainly entrepreneurship and the decision to develop it, because entrepreneurship is crucial in sylvan tourism, as in other branches of economy. The intensity of tourism, its development, and the preparation of anthropogenic tourist attractions mainly depends on the level of entrepreneurship of entrepreneurs.

To get an idea of the importance of entrepreneurship in business activity, the author carried out a questionnaire survey in Mai and June 2016. The survey consisted of 22 closed and open questions. Out of fifteen entrepreneurs (in a diagnostic survey), none of them stated that he or she was not very creative and is conducting his or her business activity proportionally at the same level. These were micro-enterprises from Hajnówka country (5 entities), 10 small enterprises from the country of Bielsk Podlaski (6 entities) and 4 entities from Białystok country. They were the entities that specialize in wood processing, forestry, tourism and catering. Only four out of fifteen respondents of selected companies stated that there had been a health determinant as an obstacle to achieving better results. The answer to the question concerning unsatisfactory results of the entity was most often confined itself to place the blame on the state or regional politics or the lack of financial resources. In the research, I also used the analysis of the source literature.

\section{Entrepreneurship in the light of the subject literature}

Entrepreneurship is a complex and multifaceted concept. An entrepreneurial attitude has been promoted in society around the world, and thus in Poland, for many years. In the subject literature entrepreneurship is being formulated from different perspectives, mainly as an economic concept, but also as a social and cultural concept. In modern scientific literature, especially in the field of economics, psychology and sociology, many definitions of entrepreneurship can be found. As early as in the thirties of the last century J.A. Schumpeter (1960, p. 104) recognized entrepreneurship as one of the most crucial factors in economic development. The author expresses the view that every entrepreneur is a businessman, but not all businessmen can be entrepreneurs (Bwisa, 2010). The category of entrepreneurship first appeared in the eighteenth century in the works of A. Smith and 
J.B. Say (Bratnicki, Strużyna, 2001). According to Say, this is an action perceived from the angle of the role of the entrepreneur, who creates or controls an enterprise, sees opportunities conducive to his or her business and uses them, and is a motive force of economic changes and progress. Entrepreneurship is, in classical terms, primarily connected with innovativeness.

It must be stated that entrepreneurship is a socio-economic category, which is essential in every socioeconomic situation, at every stage of economic and civilization development of society. In academic literature, it is emphasized that "entrepreneurship can be characterized as a socially determined process of creating opportunities for creation of wealth and their creative use through using the financial, material and human as well as human and social capital in an innovative way" (Klasik, 2006). According to R.W. Griffin entrepreneurship is a process of planning, organizing and doing business as well as taking the risks associated with it (Griffin, 2014).

Entrepreneurship issues are taken in their research by scientists of various disciplines such as economics, psychology, history of economics, political science and law. It is a common view in the subject literature that the concept of entrepreneurship is not limited to the sphere of business. This is confirmed by P. Ducker, who states that entrepreneurship is not confined only to the economic sphere, although it derives from it, and that there are slight differences between entrepreneurship existing in various spheres (Drucker, 1992).

Entrepreneurship depends on individual characteristics of a person, his or her ability to perceive in a complex objective situation a chance that can produce certain benefits. It also depends on the existing motivation system. T. Kraśnicka claims that cultural factors play a vital role in the development of entrepreneurship such as value and belief systems, entrepreneurial traditions in each area, trust as a cultural asset, family model and family ties, as well as social climate favorable to or not supporting entrepreneurship (Kraśnicka, 2002). Personality traits that facilitate entrepreneurship include:

- ability and readiness to take over the initiative,

- ability to make decisions in the absence of complete information and risk tolerance,

- taking on greater responsibilities and willingness to make even a long-term effort,

- ability to understand the market needs as well as to forecast and anticipate them,

- associating information from different fields,

- ability to manage people, not just in the formal structure, but also to raise enthusiasm and trust.

Entrepreneurship is a specific human attitude towards surrounding world and people, expressing itself in a creative and active pursuit of the improvement of existing states of affairs, in readiness to undertake new activities or to extend existing ones, and the pursuit of achieving complex, usually increased, material gains that lead to perceptible increase in profit (income) and improve living and working conditions (Wiatrak, 2003). The ways of understanding the concept of entrepreneurship affect the field of entrepreneurial activity and show that everyone can perceive entrepreneurship in diverse ways. Entrepreneurship is the opposite of passivity in action as well as expectation and apathy in tricky situations. Nowadays, entrepreneurship is conditioned by the economic growth and development as well as the well-being of societies.

J. Waśkiewicz defines entrepreneurship as a specific mindset, human attitude to themselves and the surrounding world. It is also preferred way of thinking that reflects someone's feelings on a given subject. These are also human competences and capabilities in given circumstances (Waśkiewicz, 2015). In turn, F. Kapusta defines entrepreneurship as a set of human traits, which consists in the tendency to undertake new actions, to improve 
the existing elements of the environment and to have an active a creative active attitude to the surrounding reality (Kapusta, 2006).

To conclude, it is possible to accept that the richness of the interpretation of the notion of entrepreneurship manifests itself in the possibility of considering it as:

- characteristics - a set of behaviors that aim to create and implement projects aimed at achieving the intended goal with risk reduction,

- a process to create something new and valuable, with the assumption of financial risk, but also with the assumption of monetary compensation or personal satisfaction,

- the kind of human factor activity - entrepreneurship is a specific kind of human activity, where people act individually or within an organization, using emerging opportunities, by implementing projects (introducing innovations, creating new organizations or renewal of those who exist) that bring economic and noneconomic effects to their entities and surroundings.

Entrepreneurship is particularly desirable in the development of sylvan tourism due to the natural values of forest areas and their attractiveness.

\section{The realization of entrepreneurship in the development of sylvan tourism}

Entrepreneurship is the foundation of economic development. It is the pursuit of continuous change and improvement of production, services, commerce and consumption, creating new, better opportunities to meet the needs and functioning of tourism operators. It can be defined as all activities and ventures related to the pursuit of profit and taking a risk, the essence of which is producing, offering, delivering and selling products and services deemed to be beneficial to meeting the needs and contributing to the functioning of tourism industry. Entrepreneurship is not mainly about maximizing the benefits of the use of what already exists, but the essence of it is rather the creation of something new or innovative.

One very attractive and unique way of practicing tourism, which is distinguished for its destination, is tourism in forest areas. It is called sylvan tourism or sylvan tourism. This is mainly due to the environment it is organized. These are the areas where flora and fauna exists, there are some by-products, apart from wood, and there is friendly microclimate. Despite these conditions there is still some interest in recreation in such areas among various social and occupational groups. Forest areas are a desirable location for cultivating diverse types and forms of tourism (Gaworecki, 2010), but the most salient form is sylvan tourism (Michałowski, Łagowska, 2010, pp. 126-130). Sylvan tourism is also referred to as forest tourism based on forestry-recreational infrastructure, organized in forest areas, mostly by foresters themselves (www.maskulinskie.bialystok.lasy.gov.pl/.../-lasset...-/pop_up?_).

The development of sylvan tourism creates opportunities for economic activation of many economic units as well as areas with particularly high afforestation. It is usually organized in free time, and it is an important form of rest that prevents the development of civilization diseases as well as it has its role in counteracting stressful situations characteristic of modern civilization (Muszyńska, 2000). Sylvan tourism fulfills various functions because of links between tourism and the reality in which it functions and develops. Entrepreneurship skills and creativity are essential to its organization. A critical issue in the development of entrepreneurship in tourism is the identification of the elements that stimulate it, as well as those that inhibit it. To this end, several factors can be identified that affect entrepreneurship, including: 
- the intellectual potential of an individual/individuals,

- the possibility of financial support before and during activity,

- the proper selection of management as well as service and administrative staff,

- favorable policies self-government or local authorities in terms of entrepreneurship,

- competence of inhabitants living in forest lands.

Significant factors have been identified, which largely determine the development of entrepreneurship in all types of activity. In addition to these factors, there are also barriers that can make it difficult. However, the most important of these is the access to startup capital. A significant impediment in undertaking new business is also the lack of appropriate knowledge and competence necessary to carry out properly innovative investments. Acquiring knowledge and using it in practice is a big expense for the owners of the entities. This since when taking new initiatives, it is difficult to estimate risk. The effects of a project are usually spread over time, and after spending some cash, it is often observed success or failure of the entrepreneur.

From the viewpoint of the recipient, in tourist activity the most important are tourist values and attractions. It depends on them whether the customer will take advantage of the offer. While natural values and attractions are most commonly known to those seeking to take advantage of an offer, anthropogenic values and attractions can be made upgraded every season or every year. That is why every entrepreneur who waits for the purchase of his or her product or service should progressively upgrade it. In this aspect advice can be very helpful, which should not be avoided. Tourist customers using the product or service, in addition to attractions, most often expect:

- satisfactory living conditions, proportional to the price,

- ecological food products that are skillfully prepared,

- friendly atmosphere and sociable service provider,

- friendly service and varied environment in terms of nature, culture and landscape.

To meet such expectations every customer expects an enterprising service provider who is committed to meeting the needs of his or her customers. This applies to facilities located in or near forest areas such as hotels, motels, guest houses, camp sites, agritourism farms, inns, hostels, travel agencies or transport companies.

Deciding on actions to improve the competitiveness of enterprises requires the adequate knowledge, experience and abilities, which owners of business entities often not absolutely have. That is why they often declare bankruptcy, dismissing employees and not subsidizing local government budgets or creating other business entities, often less competitive and profitable. Therefore, building mechanisms of supporting the development of entrepreneurship in tourism activities in forest areas becomes something that is needed or perhaps absolute necessity.

In Poland, there are many towns and places where anthropogenic attractions could be created, which would enable visitors to spend their leisure time (Jalinik, 2016). The most interesting ones could be:

- rope parks using forest tree stand,

- recreational paths with several stations, located in forest areas, e. g. balance beams, bars and ropes to pull-up, swings, parallel bars, chess fields, tables for table tennis and others,

- bowling alleys,

- gondola gullies in surface waters of forest areas,

- the organization of recreational events such as roller skating, ball games, biking, crossing a river or a basin on a rope in a hilly or mountainous area. 
These are exemplary proposals, and after putting them into practice it is highly probable that forest areas will be transformed into attractive sports and recreational areas. To create them it is needed to be an entrepreneurial person and open to changes. How to do it and where to learn it? This is shown in Figure 1.

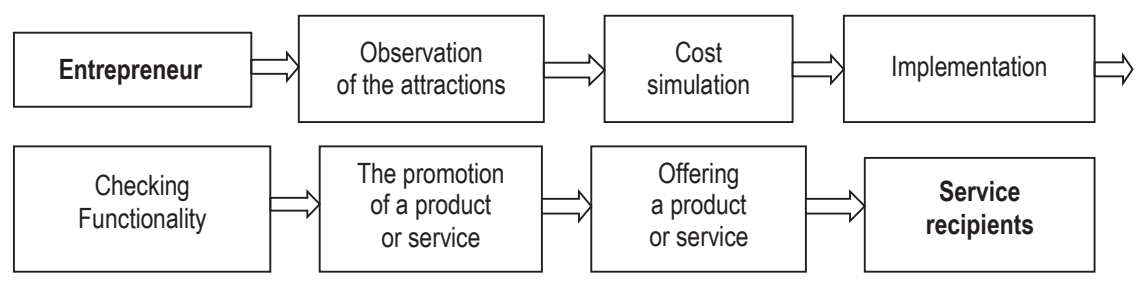

Figure 1. The process of creating attractions in forest areas

Source: own study.

To create an attraction someone should be a creative person who first analyzes and observes the planned attraction (in its site, in drawing, on a website) and then proceeds to accomplish it by performing all the steps shown in the figure. Well-prepared anthropogenic attraction arouses great interest of service recipients and it should be assumed that the profit of the business will be proportionate.

\section{Conditions for entrepreneurship in forest areas}

Entrepreneurship is a feature of personality and action that can be learned in the process of scientific and social education. The essence of entrepreneurship in a market economy is the gathering and redistribution of manufacturing factors into business environment, under the uncertainty and risk, to make a profit. The ways of understanding an entrepreneur and entrepreneurship define the area of entrepreneurial activity and make everyone perceive entrepreneurship and entrepreneur from another point of view. The economist sees the entrepreneur as an innovator who combines work, capital, resources and knowledge to gain or increase previously held value, the forester notices the internal need to use forest areas for tourism and leisure purposes. The development of entrepreneurship in forest areas should bring social and economic benefits to the local communities. The development and functioning of tourism in forest areas should involve economic functions such as commerce, catering, accommodation and transport. And local authorities should create conditions and encourage for the development of entrepreneurship.

The environment in which entrepreneurship is triggered is the market. Entrepreneurs not only adapt their activities to market conditions, but they actively shape them, creating new links between market participants. The desired ways behavior includes: innovation, responding to challenges, willingness to take a risk, thinking through the prism of recognized competitive conditions, as well as responsibility for the consequences of decisions taken and the dynamics of action.

The manifestation of the development of entrepreneurship is the broadly understood competitiveness between economic entities. Hence, it is necessary to change the attitudes of entrepreneurs and to open to cooperation with other entrepreneurs or to benefit from broadly understood advice. In case of the appearance of barriers the reason may be too low level of initial education, often referred to as one of the reasons for the development of entrepreneurship in tourist entities. Considerable influence on the development of entrepreneurship may have 
qualified staff and a specialized training system. Tourist service providers should be interested in entrepreneurship related to the diverse types and forms of tourism and recreation.

Conditions for the development of entrepreneurship are accurately defined by K. Krajewski, who thinks that entrepreneurship is the result of individual traits of people (talents, skills, energy, imagination, common sense, and willingness to take a risk) and socio-economic characteristics generated in their environment (resource availability, local economic traditions, social absorption capacity of business initiatives, socio-economic policies, and local climate around business activities) (Krajewski, 2002).

The experience of people who have gained (or lost) a fortune because of their entrepreneurial activity can be a subject of fascinating stories, but even more comes from the fact that entrepreneurship plays a vital role in our society and tourist economy (Griffin, 2014).

The manifestation of entrepreneurial attitudes is dependent on the existence of certain objective and subjective conditions. According to J. Sikora (2012, p. 58) objective conditions belong to so-called external conditions, which should provide freedom of choice. In such conditions, everyone can influence his or her own situation and development. Such objective conditions include: market economy, stable legal regulations, economic, tax and credit properties, economic equilibrium, economic autonomy of business entities as well as their diversity and organizational culture. In turn, according to the author, subjective conditions include: know-how, qualifications and motifs, as well as personal qualities, including courage, energy, willingness to risk, diligence, intelligence, ability to cooperate with people, solidarity, honesty, ability to learn and adapt to changing conditions, ability to predict, easiness in communication with other people, determination and persistence, optimism, and the need for achievement.

\section{Conclusions}

Forest management is governed by several regularities and rules. It is a mechanism whose function is constantly influenced by several factors. Forest areas are a desirable destination for tourism (sylvan tourism) because of their calmness, the lack of pollution and noise, but its success depends on tourist infrastructure and the creativity of the originator. It is also worth remembering that one of the basic determinants of its development is the state policy. Every time it can be said that politicians are shaping the stage where entrepreneurs operate (bans and orders). Polish economy, as it is known, is based on market mechanisms. Hence, it is extremely important to make changes to determine the optimal direction for the further development of the tourism industry. Entrepreneurship raises competitiveness and where there is a large group of enterprising people, there is, in financial terms, a better place for people to live.

In addition, entrepreneurship produces uneconomical effects in the form of changing the consciousness of the inhabitants of adjacent villages. Based on the discussion with the owners of the surveyed entities every one of them considers himself or herself as an entrepreneur, but when it comes to concrete achievements, then entrepreneurship is practically imperceptible. Therefore, the development of entrepreneurship requires broad interdisciplinary knowledge and considerable skills that are still low among the rural population.

This is especially important in tourism activity in forest areas due to the seasonal nature of its many products and its place (unpolluted environment). If a customer has not been satisfied with the purchase of a product in each year, then he or she will not certainly use the same product and the place of its purchase for some years. 


\section{References}

Bwisa, H.M. (2010). The Visible Hand, Entrepreneurship Resource Website, www.professorbwisa.com (7.01.2010).

Bratnicki, M., Strużyna, J. (2001). Przedsiębiorczość i kapitał intelektualny. Katowice: Wydawnictwo Akademii Ekonomicznej w Katowicach.

Drucker, P.F. (1992). Innowacje i przedsiębiorczość. Praktyka i zasady. Warszawa: PWE.

Gaweł, A. (2007). Ekonomiczne determinanty przedsiębiorczości. Prace Habilitacyjne 34. Poznań: Akademia Ekonomiczna w Poznaniu. Gaworecki, W.W. (2010). Turystyka. Warszawa: PWE.

Griffin, R.W. (2014). Podstawy zarządzania organizacjami. Warszawa: Wydawnictwo Naukowe PWN.

Jalinik, M. (2016). Zarządzanie turystyką na obszarach leśnych. In: M. Jalinik, S. Bakier (eds.), Turystyka na obszarach przyrodniczo cennych (pp. 78-79). Białystok: EkoPress.

Kapusta, F. (2006). Przedsiębiorczość - teoria i praktyka. Poznań: Wydawnictwo Wyższej Szkoły Zarządzania i Bankowości w Poznaniu. Krajewski, K. (2002). Przedsiębiorczość i integracja. Decydent, 6 (34).

Klasik, A. (2006). Przedsiębiorczość i konkurencyjność a rozwój regionalny. Katowice: AE w Katowicach.

Kraśnicka, T. (2002). Koncepcja rozwoju przedsiębiorczości ekonomicznej i pozaekonomicznej. Katowice: Wydawnictwo AE w Katowicach.

Michałowski, K., Łagowska, B. (2007). Wybrane elementy turystyki wiejskiej ze szczególnym uwzględnieniem turystyki i rekreacji na obszarach zalesionych. In: M. Jalinik (ed.), Rozwój turystyki na obszarach wiejskich (pp. 126-130). Białystok: Wydawnictwo Politechniki Białostockiej.

Muszyńska, B. (2000). Walory zdrowotne zbiorowisk leśnych. In: K. Pieńkoś (ed.), Problemy turystyki i rekreacji w lasach Polski. Warszawa: Wydawnictwo PTL, Komisja Inżynierii Leśnej i Gospodarki Wodnej.

Sikora, J. (2012). Agroturystyka. Przedsiębiorczość na obszarach wiejskich. Warszawa: C.H. Beck.

Schumpeter, J.A. (1960). Teoria rozwoju gospodarczego. Warszawa: PWN.

Waśkiewicz, J. (2015). Przedsiębiorczość: istota, pojęcie i jej rodzaje. Zarządzanie. Przedsiębiorczość. Innowacyjność, 1, 13.

Wiatrak, A.P. (2003). Pojęcie przedsiębiorczości, jej cele i rodzaje. In: K. Jaremczuk (ed.), Uwarunkowania rozwoju przedsiębiorczości - szanse i zagrożenia. Tarnobrzeg: Wydawnictwo PWSZ.

Cite this apticle aS: Jalinik, M. (2017). Entrepreneurship in the development of sylvan tourism. European Journal of Service Management, 3 (23), 31-38. DOI: 10.18276/ejsm.2017.23-04. 